\title{
Factors for Cross-disciplinary Research Collaboration: Experiences of Researchers at the Faculty of Engineering and Built Environment, UKM
}

\author{
Mohd Huzairi Johari ${ }^{1}$, Roslena Md Zaini ${ }^{2} \&$ Muhammad Fauzi Mohd Zain ${ }^{3}$ \\ ${ }^{1}$ Centre for Engineering Education Research, Faculty of Engineering and Built Environment, Universiti \\ Kebangsaan Malaysia, Selangor, Malaysia \\ ${ }^{2}$ Advanced Engineering Centre, Faculty of Engineering and Built Environment, Universiti Kebangsaan Malaysia, \\ Selangor, Malaysia \\ ${ }^{3}$ Department of Architecture, Faculty of Engineering and Built Environment, Universiti Kebangsaan Malaysia, \\ Selangor, Malaysia
}

Correspondence: Mohd Huzairi Johari, Centre for Engineering Education Research, Faculty of Engineering and Built Environment, Universiti Kebangsaan Malaysia, 43600 UKM Bangi, Selangor, Malaysia. Tel: 60-3-8921-6111; 60-3-8911-8316. E-mail: ujay4689@gmail.com

Received: September 24, 2012 Accepted: November 7, 2012 Online Published: November 30, 2012

doi:10.5539/ass.v8n16p122

URL: http://dx.doi.org/10.5539/ass.v8n16p122

\begin{abstract}
Cross-disciplinary research is a research activity that involves researchers of multiple disciplines in studying new knowledge. Cross-disciplinary research extends beyond simple collaboration to integrate data, methodologies, perspectives and concepts from various fields to understand the basics or find the solution for real world problems. The approach of cross-disciplinary research taken at the Faculty of Engineering and Built Environment (FKAB), in transforming the researcher, is still deem to be at its minimum because there has yet to be a study on unravelling the difficulties and challenges of reinforcing cross-disciplinary research. Furthermore, the absence of a guideline for conducting such research prohibits the researcher to pursue his research into different discipline. The purpose of this paper is to examine the challenge and difficulty factors that contribute to the less than effective cross-disciplinary researches at the FKAB in particular, and in UKM in general. In addition, through the conducted data analysis, a preliminary guideline can be formed, which can then be used as a guide and resource to develop awareness and capability in implementing cross-disciplinary research. The study was conducted using qualitative and quantitative methods. The qualitative method taken was distributing a questionnaire to academicians at the FKAB. Data obtained are then analysed using WinSteps 3.68.2, which is software utilised in Rasch analysis. Overall, results show that the main factor contributing to difficulties in implementing cross-disciplinary research is the need for solid financial funding.
\end{abstract}

Keywords: cross-disciplinary research, measurement, rasch model, Winstep 3.68.2, researcher

\section{Introduction}

Cross-disciplinary research offers the opportunity to open new fields in research, using varying expertise to explore similar issues, solve complicated problems and increase returns of investment made for research by utilizing the knowledge, instruments, methods and solutions generated by one discipline into another (Gayraud, 2005). Scientists, policymakers and managers have begun to encourage and advocate cooperation between various disciplines in research and development, as well as in basic and applied sciences (Chin et al., 2002; Grinter et al., 1999; Teasley \& Wolinsky, 2001).

Similar cross-disciplinary research can only improve and enhance innovations, whereas divergent cross-disciplinary research can generate new ideas and produce fresh and advance technologies. In the past, collaboration between researchers was difficult. The physical distance between them not only lessens the likelihood of collaboration but also had a negative impact on the success of the research (Allen, 1977; Kiesler \& Cummings, 2002; Kraut et al., 1990). Today, collaborations between researchers are aided by tools and technologies that enable them to share information, data, reports, instruments and other resources. The Internet and various softwares can also increase the potential for a researcher to contribute brains and brawn in a 
cross-disciplinary research for the benefit of all. Therefore, the possibility of collaboration between researchers nowadays is high. With that said however, there are challenges and difficulties that may prevent cross-disciplinary research to be successful.

The recognition of UKM as a Research University has inspired researchers to conduct research with cross-disciplinary focus. This is due to the increment of research grants allocated by the university's research fund. In the Transformation Strategy of UKM, the first strategy is to focus and bring together expertise from different disciplines to work in 8 niche areas that are identified as UKM's strengths and potentials. Research transmission move so drastically and so, it requires full commitment and competency from FKAB researchers to conduct cross-disciplinary research. FKAB is one of the faculty in UKM that have higher number of article produced from the every research have done. For the year 2011 a total of 1724 articles were published by FKAB. This is a case study to identify the challenges and difficulties that affect the success of cross-disciplinary research at FKAB. And so, evaluation and measurements need to be taken in order to identify the most important factor that can lead to the success of a cross-disciplinary research. Through analysis of the data obtained, a preliminary guideline can be developed as a guide to develop awareness of implementing cross-disciplinary research at FKAB and others institution.

\section{Methodology}

The study that lead to cross-disciplinary research was done by using questionnaires that were distributed to all academic staff in FKAB. There are 5 departments and 1 unit under the FKAB namely the Department of Civil And Structural Engineering (JKAS), Department of Electric, Electronic and Systems Engineering (JKEES), Department of Chemical and Process Engineering (JKKP), Department of Mechanical and Materials Engineering (JKMB), Department of Architecture (JSB) and Unit of Fundamental Engineering Studies (UPAK). From 5 departments and 1 unit, a total of $(\mathrm{N}=43)$ respondents answered this questionnaire. The study used a 5-point Likert scale questionnaire, where 1 represents strongly disagree and 5 represents strongly agree. The main discussion in this paper is to discuss the factors that influence the conduct of cross-disciplinary research. The factors involved in the questionnaire are shown in Table 1.

Table 1 . The factors for cross-disciplinary research

\begin{tabular}{|c|c|c|c|c|c|c|}
\hline No. & Factor & $\begin{array}{l}\text { Strongly } \\
\text { Disagree }\end{array}$ & Disagree & $\begin{array}{l}\text { Less } \\
\text { Agree }\end{array}$ & Agree & $\begin{array}{l}\text { Strongly } \\
\text { Agree }\end{array}$ \\
\hline 1. & $\begin{array}{l}\text { Tendency for } \quad \text { cross-disciplinary } \\
\text { research }\end{array}$ & 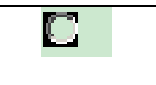 & $\bar{C}$ & D & $\mathbb{C}$ & $\mathrm{C}$ \\
\hline 2. & Solidity of financial resource & 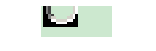 & $\leftarrow$ & $\omega$ & 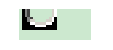 & $\omega$ \\
\hline 3. & Requirement for expertise & 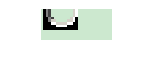 & 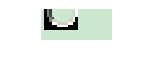 & 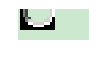 & 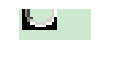 & 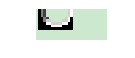 \\
\hline 4. & Capability to conduct research & L & $\leftarrow$ & $\omega$ & $\omega$ & $\omega$ \\
\hline 5. & Exposure cross-disciplinary research & 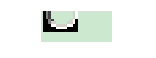 & $\leftarrow$ & 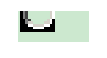 & 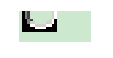 & $\mathbf{L}$ \\
\hline 6. & $\begin{array}{l}\text { Capability to } \\
\text { cross-disciplinary research }\end{array}$ & $\mathrm{C}$ & C & $\mathrm{C}$ & $\mathrm{C}$ & $\square$ \\
\hline 7. & Strength of research staff & $\omega$ & $\mathbf{L}$ & $\omega$ & 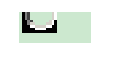 & $\omega$ \\
\hline 8. & $\begin{array}{l}\text { Ability to work as a team (between } \\
\text { researchers) }\end{array}$ & C & C & C & C & C \\
\hline 9. & $\begin{array}{l}\text { Support from management - faculty / } \\
\text { UKM }\end{array}$ & C & C & C & C & C \\
\hline 10. & Tendency for individual research & $\mathbf{L}$ & $\leftarrow$ & $\leftarrow$ & $\leftarrow$ & $\leftarrow$ \\
\hline 11. & $\begin{array}{l}\text { Distance constraints with other } \\
\text { researchers }\end{array}$ & E & $\mathbb{E}$ & C & E & E \\
\hline 12. & $\begin{array}{l}\text { Time constraints in conducting } \\
\text { research }\end{array}$ & E & C & C & C & C \\
\hline 13. & Period of time given by grant provider & $\leftarrow$ & 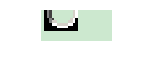 & $\leftarrow$ & $\leftarrow$ & 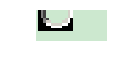 \\
\hline 14. & Research networking & 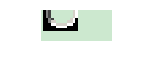 & $\leftarrow$ & 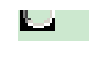 & $\leftarrow$ & L \\
\hline 15. & Communication in research & 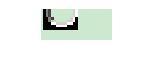 & 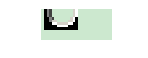 & 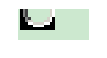 & $\omega$ & 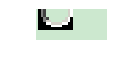 \\
\hline 16. & Stability of research management & $\omega$ & $\mathbf{L}$ & L & $\omega$ & $\omega$ \\
\hline 17. & Research Infrastructure & $\omega$ & 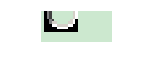 & $\omega$ & $\leftarrow$ & $\omega$ \\
\hline
\end{tabular}

Data were analysed using Excel spread sheet and then transferred into the WinStep 3.68.2, Rasch model analysis. 
In Rasch model, the probability of success can be estimated for the maximum likelihood of an event (Bond and Fox 2007).

$$
p(\theta)=\frac{e^{\beta_{n}-\delta_{i}}}{1+e^{\beta_{n}-\delta_{i}}} \mathrm{e}
$$

Where:

$e=$ base of natural algorithm or Euler's number

$\beta_{n}=$ person or respondent's ability

$\delta_{i}=$ item difficulty

$p(\theta)=$ probability of person $\theta$ giving the rating

These items difficulty and person ability estimates are then expressed on scale of odd ratios, or logits. The average logit is arbitrarily set at 0 with positive logits indicating higher than average probabilities and negative logits indicating lower than average probabilities (Bond \& Fox, 2007).

The item-person interaction indicates the degree to which respondents answer items of different 'difficulty' in a logical and consistent manner. When the data fit the model, the fit statistic has a mean near zero and a standard deviation near 1 (Robert et al., 2003). Rasch Model also produces an item map displaying location of item thresholds and location of respondents.

\section{Results and Discussion}

The results from data survey are tabulated and executed in WinStep3.68.2 software. It shows the item representing factors that contribute to a cross-disciplinary research being carried out, while person represents the respondent. Figure 1 shows a summary of the statistics for person and item category with a good reliability of Cronbach- $\alpha=0.87$, which indicates that the respondent target group was correctly chosen. Also, the questionnaire was constructed with brief and clear items and information. The analysis identified two groups of respondent separation; $G=2.31$ with group of respondents that have no problem at all in conducting cross-disciplinary research, while the other group of respondent were facing problem in conducting cross-disciplinary research. For summary of item measured, item reliability of $\approx 0.8$ indicates that the factors are reliable in measuring what is supposed to be measured. On the other hand, the item summary gives a good summary with separation $\mathrm{G} \approx 2.0$ and a good reliability $\approx 0.8$.

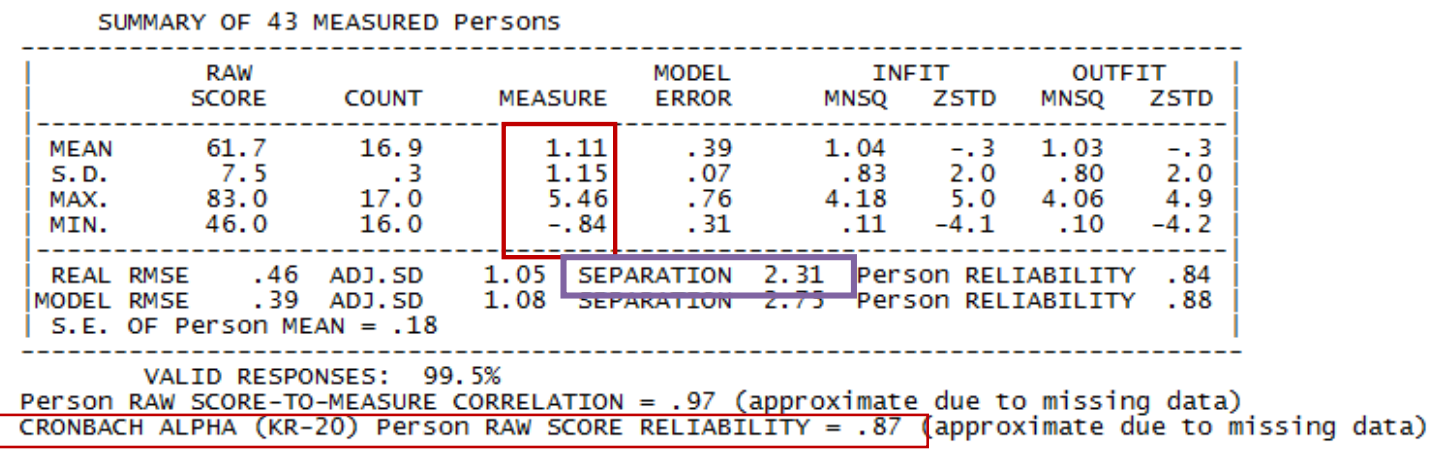

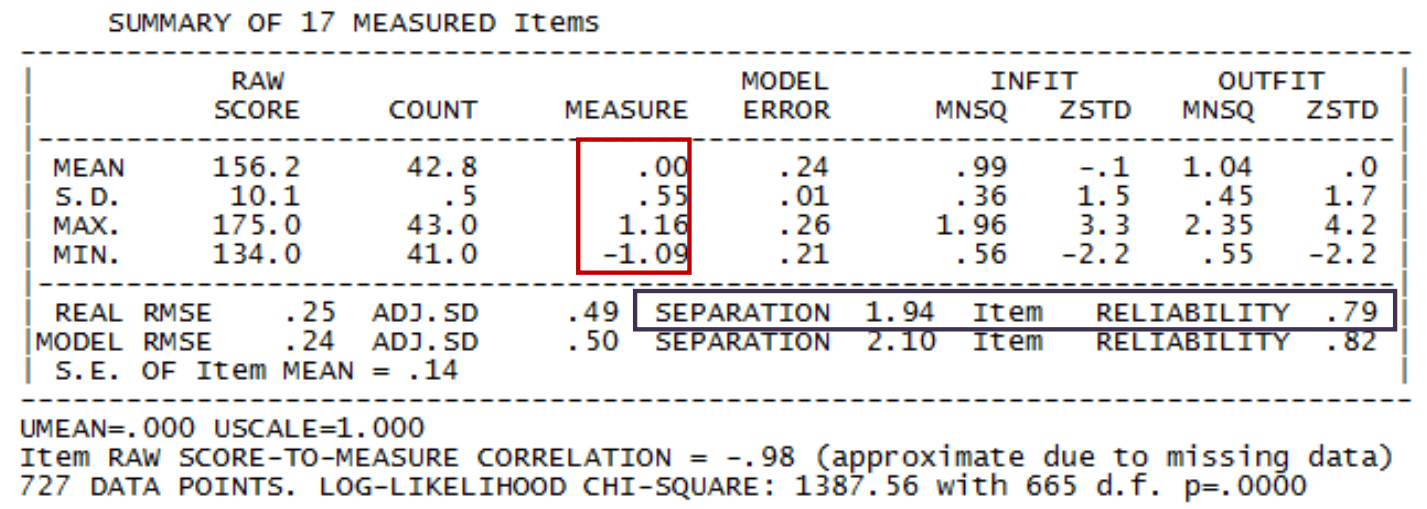

Figure 1. Summary statistics: Person and item measure 
Figure 2 shows the Person-Item Distribution Map (PIDM). It is found that person distribution, which is plotted on the same logit scale, is more distributed compare to item distribution. Value for person distribution is spread in place from 5.46 logit until -0.84 logit, where as item distribution only spread in position 1.16 logit until -1.19 logit. This clearly shows that many respondents agreed to the factor of financial resources is the most important factor in doing cross-disciplinary research, while expertise resource is the lowest factor that gives no constraints on the respondent to conduct research.

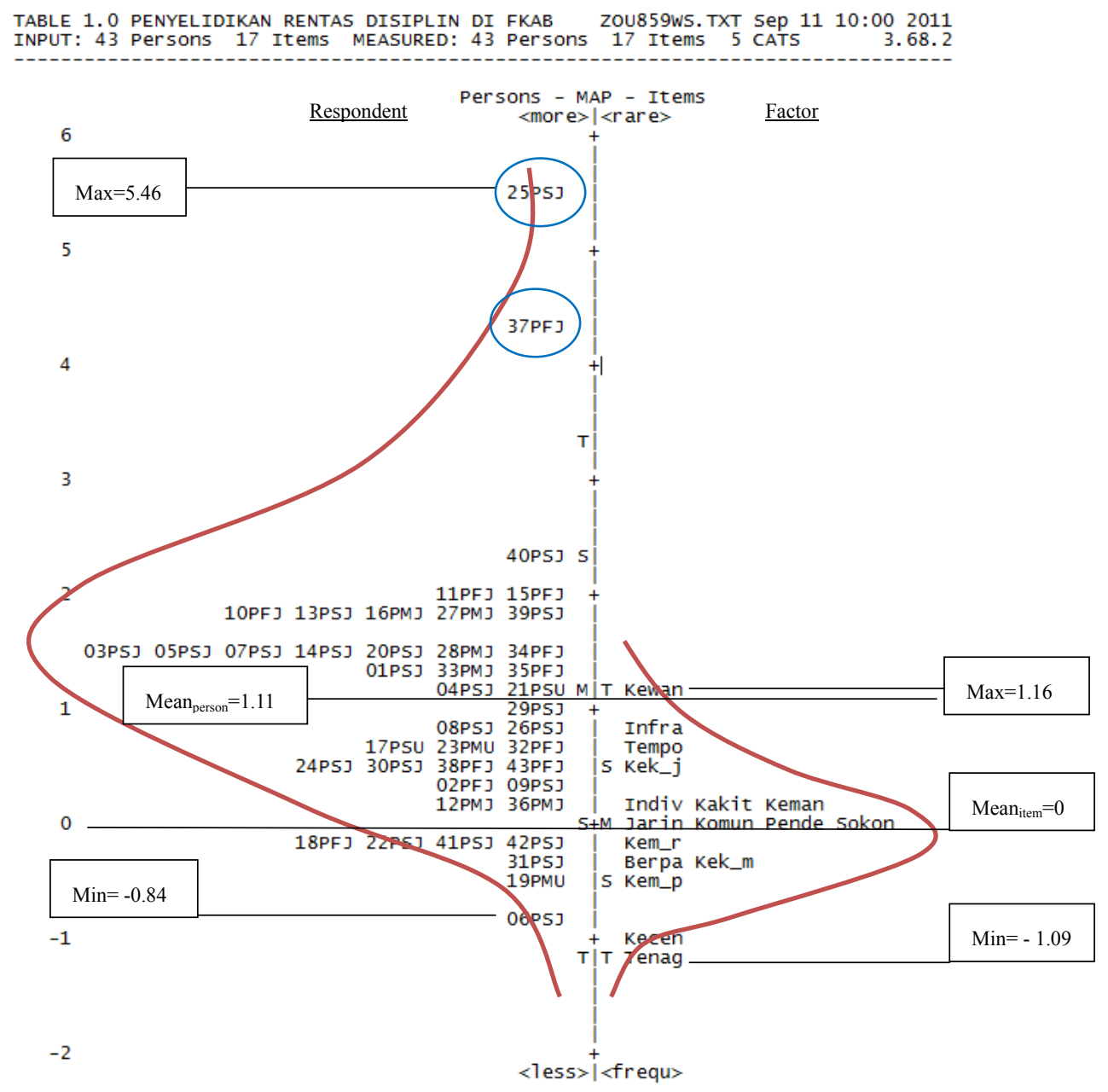

Figure 2. Item-person map for factors in implementing cross-disciplinary research

According to Figure 2, the person mean value, Mean $_{\text {person }}$ is 1.11 , which is a positive value more than Mean $_{\text {item }}=$ 0 .These values show that performance of respondent in cross-disciplinary research is above the expected performance. This means that more than half of the respondents $(\mathrm{N}=36,83.7 \%)$ did not experience problems in cross-disciplinary research, where the respondents are not affected by most of the factors mentioned. 25PSJ and $37 \mathrm{PFJ}$ is two respondents who are successful in carrying out cross-disciplinary research. Respondent 25PSJ is a lecturer who has 6-10 years of experience in research and has had a variety of research grants. This provides an advantage to 25PSJ to excel in cross-disciplinary research. While, respondent 37PFJ is a professor that has more than 15 years of experience and also has had a lot of grants, where one of them was an international grant. This obviously shows that financial resource plays a key role to cross-disciplinary research as well as the researchers' experiences. Other than that, the resource of expertise was not found to be a constraining factor as it located at the bottom of the item distribution. 
TABLE 13.1 PENYELIDIKAN RENTAS DISIPLIN DI FKAB ZOU859WS. TXT Sep 11 10:00 2011 INPUT: 43 Persons 17 It Iems MEASURED: 43 Persons 17 Items 5 CATS 3.68 .2

Person: REAL SEP.: 2.31 REL.: .84 ... Item: REAL SEP.: 1.94 REL.: .79

ITEm STATISTICS: MEASURE ORDER

\begin{tabular}{|c|c|c|c|c|c|c|c|c|c|c|c|c|c|}
\hline $\begin{array}{l}\text { ENTRY } \\
\text { NUMBER }\end{array}$ & $\begin{array}{l}\text { TOTAL } \\
\text { SCORE }\end{array}$ & COUNT & MEASURE & $\begin{array}{l}\text { MODEL } \\
\text { S.E. }\end{array}$ & $\mid$ MNSQ & $\begin{array}{l}\text { FIT } \\
\text { ZSTD }\end{array}$ & $\begin{array}{r}\text { OU } \\
\text { MNSQ }\end{array}$ & $\begin{array}{l}\text { FIT } \\
\text { ZSTD }\end{array}$ & $\begin{array}{l}\text { PT-MEA. } \\
\text { EORR. }\end{array}$ & $\begin{array}{l}\text { URE } \\
\text { EXP. }\end{array}$ & \begin{tabular}{|} 
EXACT \\
OBS\%
\end{tabular} & $\begin{array}{r}\text { MATCH } \\
\text { EXP\% }\end{array}$ & Item \\
\hline $\begin{array}{r}2 \\
17 \\
13 \\
11 \\
10 \\
7 \\
16 \\
5 \\
15 \\
9 \\
14 \\
6 \\
12 \\
8 \\
4 \\
1 \\
3\end{array}$ & $\begin{array}{l}134 \\
143 \\
142 \\
148 \\
149 \\
156 \\
156 \\
157 \\
157 \\
158 \\
158 \\
160 \\
162 \\
164 \\
167 \\
169 \\
175\end{array}$ & $\begin{array}{l}43 \\
43 \\
42 \\
43 \\
41 \\
43 \\
43 \\
43 \\
43 \\
43 \\
43 \\
43 \\
43 \\
43 \\
43 \\
42 \\
43\end{array}$ & $\begin{array}{r}1.16 \\
.75 \\
.62 \\
.51 \\
.15 \\
.09 \\
.09 \\
.03 \\
.03 \\
-.02 \\
-.02 \\
-.14 \\
-.26 \\
-.38 \\
-.56 \\
-. .95 \\
-1.09\end{array}$ & $\begin{array}{l}.21 \\
.22 \\
.22 \\
.22 \\
.24 \\
.23 \\
.23 \\
.24 \\
.24 \\
.24 \\
.24 \\
.24 \\
.24 \\
.25 \\
.25 \\
.26 \\
.26\end{array}$ & \begin{tabular}{|r}
1.26 \\
1.39 \\
1.09 \\
.98 \\
1.96 \\
.88 \\
.56 \\
.88 \\
.72 \\
1.35 \\
.80 \\
.58 \\
.80 \\
.80 \\
.57 \\
1.28 \\
.94
\end{tabular} & $\begin{array}{r}1.2 \\
1.7 \\
.5 \\
.0 \\
3.3 \\
-.4 \\
-2.2 \\
-.4 \\
-1.3 \\
1.4 \\
-.8 \\
-2.0 \\
-.8 \\
-.8 \\
-2.1 \\
1.2 \\
-.2\end{array}$ & $\begin{array}{r}1.32 \\
1.47 \\
1.07 \\
1.01 \\
2.35 \\
.84 \\
.56 \\
.88 \\
.73 \\
1.39 \\
.73 \\
.62 \\
.83 \\
.79 \\
1.55 \\
1.65 \\
.91 \\
\end{array}$ & $\begin{array}{r}1.5 \\
2.0 \\
.4 \\
.1 \\
4.2 \\
-2.6 \\
-2.2 \\
-.4 \\
-1.2 \\
1.5 \\
-1.2 \\
-1.8 \\
-.6 \\
-.9 \\
-2.1 \\
2.3 \\
-.3\end{array}$ & \begin{tabular}{|c|}
.53 \\
.52 \\
.62 \\
. .41 \\
-.01 \\
.67 \\
.74 \\
.53 \\
.68 \\
.56 \\
.69 \\
.62 \\
.54 \\
.70 \\
.56 \\
.38 \\
.45
\end{tabular} & $\begin{array}{l}.59 \\
.57 \\
.57 \\
.56 \\
.53 \\
.54 \\
.54 \\
.54 \\
.54 \\
.54 \\
.54 \\
.53 \\
.53 \\
.52 \\
.51 \\
.50 \\
.48\end{array}$ & $\begin{array}{l}53.5 \\
55.8 \\
54.8 \\
46.5 \\
46.3 \\
58.1 \\
79.1 \\
62.8 \\
62.8 \\
62.8 \\
60.5 \\
76.7 \\
55.8 \\
60.5 \\
76.7 \\
57.1 \\
62.8\end{array}$ & $\begin{array}{l}49.8 \\
52.6 \\
53.9 \\
55.2 \\
57.7 \\
58.2 \\
58.2 \\
58.5 \\
58.5 \\
58.7 \\
58.7 \\
59.8 \\
60.4 \\
61.2 \\
62.0 \\
62.3 \\
62.6\end{array}$ & $\begin{array}{l}\text { Kewangan } \\
\text { Infrastruktur pnyelidikan } \\
\text { Tempoh masa diperuntukkan } \\
\text { Kek_jarak } \\
\text { Individu } \\
\text { Kakitangan } \\
\text { Kemantapan pengurusan penyelidikan } \\
\text { Pendedahan rentas disiplin } \\
\text { Komunikasi dalam penyelidikan } \\
\text { Sokongan pengurusan } \\
\text { Jaringan penyelidikan } \\
\text { Kem_rentas_disiplin } \\
\text { Kek_masa } \\
\text { Berpasukan } \\
\text { Kem_penyelidikan } \\
\text { Kecenderungan rentas disiplin } \\
\text { Tenaga pakar }\end{array}$ \\
\hline $\begin{array}{l}\text { MEAN } \\
\text { S.D. }\end{array}$ & $\begin{array}{r}156.2 \\
10.1\end{array}$ & $\begin{array}{r}42.8 \\
.5\end{array}$ & $\begin{array}{l}.00 \\
.55\end{array}$ & .24 & \begin{tabular}{|l}
.99 \\
.36
\end{tabular} & $\begin{array}{l}-.1 \\
1.5\end{array}$ & $\begin{array}{r}1.04 \\
.45\end{array}$ & & & & $\begin{array}{r}60.7 \\
9.2\end{array}$ & $\begin{array}{r}58.1 \\
3.4\end{array}$ & \\
\hline
\end{tabular}

Figure 3. Item measure

Point measure correlation in this case is shown in Figure 3. Referring to the 'Point measure correlation (Pt-measure corr.)', 'Outfit mean square (MNSQ)' and 'Outfit Z-standard (ZSTD)', all 17 factors are checked to determine misfit item. The factors are said to be a misfit when the three value are outside of the range $0.4<$ Pt-measure corr. $<0.8$ for point measure correlation, $0.5<$ Outfit MNSQ $<1.5$ for Outfit mean square (MNSQ) and outfit $z$-standard (ZSTD) $-2<$ Outfit ZSTD $<2$. By checking each factor, it was found that the tendency of conducting cross-disciplinary research and the tendency to conduct research individually are categorized as misfit factors. It indicates that the factors need to be further evaluated.

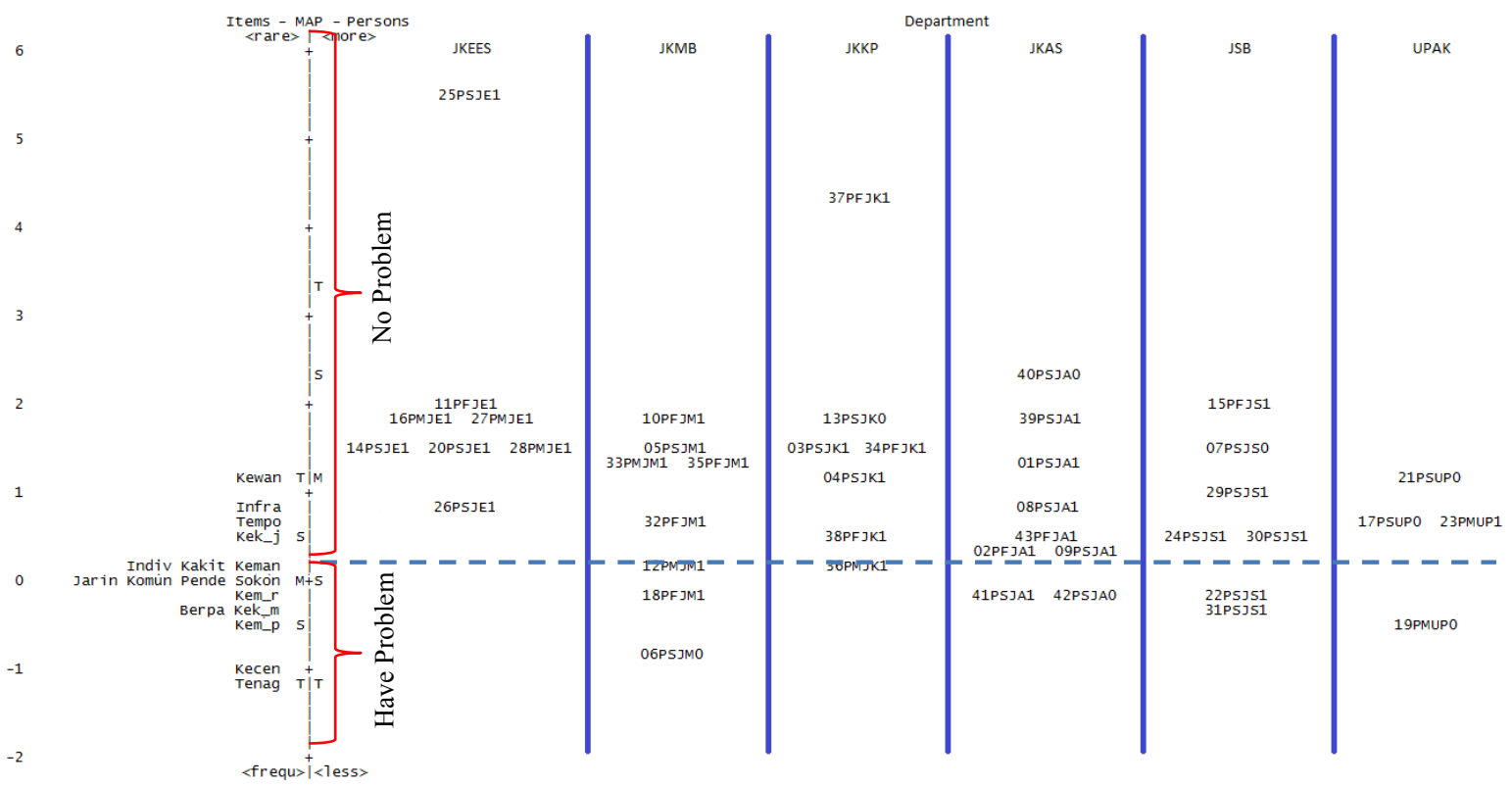

Figure 4. PIDM distributed by department.

Figure 4 shows the person measure according to departments. Overall, $83.7 \%(\mathrm{~N}=36)$ had no problem of conducting cross-disciplinary research. As we can see, the person measure is categorized into two categories. The categories are the group of researchers that have no problem with the factors of doing cross-disciplinary research and the group of researchers that have a problem with the factors of doing cross-disciplinary research. It was noted that $100 \%$ of JKEES and JKKP had no problem with the factors. As for JKAS, $77.77 \%(\mathrm{~N}=7)$ had no problem, $75 \%$ of both JKMB $(\mathrm{N}=6)$ and UPAK $(\mathrm{N}=3)$ had no problem, and $71.43 \%(\mathrm{~N}=5)$ of JSB had no problem. The ratio obtained shows that the majority of each department did not have a problem with the factors of doing cross-disciplinary research. Every department has contributed to cross-disciplinary research. 


\section{Conclusion}

Studies have shown that the response of the academic staff toward the factors required in implementing cross-disciplinary research have a good reliability with value of Cronbach- $\alpha=0.87$. This research has identified that the main factor, which creates a challenge in cross-disciplinary research, is the financial factor. A good financial were need for a better research. It has been proven by the Rasch analysis implemented. From the PIDM, it is shown that items with most difficulty will be at the top. Additionally, expertise was found to be the lowest item. It means that the resource of expertise was not an issue at all in implementing cross-disciplinary research. Even though the financial issue was the main factor, half of the respondents did not have a problem with it. It can be described that there are factors other than the 17 factors mentioned in the questionnaire form. Improvements must be made to the item (factor) because there is the probability for other significant factors influencing the implementation of cross-disciplinary research.

Cross-disciplinary research at the FKAB is implemented by all of the departments and unit without having a problem with the factors, which may influence the research itself and the researchers. This means that most FKAB researchers are supportive of UKM's strategy to focus and bring together expertise from various disciplines to work in eight niche areas that have been identified.

In the future, another case study will be done to find other factors that may create a constraint for the researchers to conduct cross-disciplinary research. This study can be an observational tool and is beneficial in understanding the factors for implementing cross-disciplinary research. The Rasch measurement model is a useful tool in analyzing data collected from the questionnaires and also, in providing depth analysis that includes reliability of the questions (factors) and the respondents.

\section{Acknowledgements}

This research is supported by grant PTS-2011-151 under UKM Action Strategic Fund and OUP-2012-126. The authors would like to thank the Centre of Engineering Education in Universiti Kebangsaan Malaysia, Bangi, Selangor, Malaysia for their support in this study.

\section{References}

Allen, T. (1997). Managing the Flow of Technology. Cambridge, MA. MIT Press.

Bond, T. G., \& Fox, C. M. (2007). Applying the Rasch Model: Fundamental measurement in the human sciences (2nd ed.).

Chin, G., Myers, J., \& Hoyt, D. (2002). Social networks in the virtual science laboratory. Communications of the $A C M, 45(58), 87-92$. http://dx.doi.org/10.1145/545151.545156

Gayraud, Y. (2005). Cross-disciplinary Report in FET.

Grinter, R., Herbsleb, J., \& Perry, D. (1999). The Geography of Coordination: Dealing with Distance in R\&D Work, in Proceedings of GROUP, Phoenix, AZ, November 14-17.

Kiesler, S., \& Cummings, J. (2002). What Do We Know About Proximity and Distance in Work Groups? In P. Hinds, \& S. Kiesler (Eds.), Distributed Work (pp. 57-80). Cambridge, MIT Press.

Kraut, R., Egido, C., \& Galegher, J. (1990). Patterns of Contact and Communication in Scientific Research Collaboration. In J. Galegher, R. Kraut, \& C. Egido (Eds.), Intellectual Teamwork: Social and Technological Bases of Cooperative Work (pp. 149-171). Hillsdale, NJ. Lawrence Erlbaum.

Robert F. C., Joseph R., Geoffrey J. G., Melinda H., \& Graham B. D. (2003). Application of Rasch Model and traditional statistics to develop a measure of primary school classroom learning culture, paper presented at the 2003 Annual Conference of the Australian Association for Research in Education: Auckland, New Zealand.

Teasley, S., \& Wolinsky, S. (2001). Scientific collaborations at a distance. Science, (292), 2254-2255. http://dx.doi.org/10.1126/science.1061619 